\title{
Partial internal hemipelvectomy as rescue therapy in obstipation in four dogs: case report
}

\author{
[Hemipelvectomia caudal parcial interna como terapia de salvamento na obstipação \\ em quatro cães: relato de caso] \\ R.C. Costa $^{1}$, P.P. Rossignoli ${ }^{1}$, A.C. Facin ${ }^{1}$, T.L. Nazaret ${ }^{1}$, B.W. Minto ${ }^{2}$, L.G.G.G. Dias ${ }^{2 *}$ \\ ${ }^{1}$ Aluno de pós-graduação - Universidade Estadual Paulista "Julio de Mesquita Filho" - UNESP Jaboticabal, SP \\ ${ }^{2}$ Universidade Estadual Paulista "Julio de Mesquita Filho" - UNESP Jaboticabal, SP
}

\begin{abstract}
Multiple pelvic fractures can lead to narrowing of the pelvic canal and loss of life quality. Hemipelvectomy, characterized by removal of bone fragments from the pelvis, is considered a rescue therapy. This report describes the technique of caudal partial hemipelvectomy in four cases of obstipation secondary to traumatic pelvic canal narrowing in four dogs, with promising results. All patients had tenesmus and fecal retention. After the procedure, the patients presented immediate normochezia and support of the ipsilateral limb after 10 to 20 days, showing the feasibility of the technique in small animals, providing clinical improvement without walking alterations.
\end{abstract}

Keywords: canine, obstipation, pelvic canal stenosis, pelvis, surgery

\section{RESUMO}

Múltiplas fraturas da pelve podem gerar angústia pélvica. A hemipelvectomia, caracterizada pela remoção de fragmentos ósseos da pelve, é considerada terapia de salvamento. O presente relato descreve a técnica de hemipelvectomia interna parcial em quatro casos de obstipação por angústia pélvica traumática em cães, com resultados alvissareiros. Todos os pacientes apresentavam tenesmo e retenção fecal. Após a realização do procedimento, os pacientes apresentaram normoquesia imediata e apoio do membro ipsilateral ao procedimento após 10 a 20 dias, mostrando a exequibilidade da técnica em animais leves, uma vez que houve melhora clínica sem alterações na deambulação.

Palavras-chave: canino, constipação, estenose do canal pélvico, pelve

\section{INTRODUCTION}

The pelvis is composed of the ilium, ischium, and pubis. It is united ventrally at the pubic symphysis and articulates dorsally with the sacrum and thus has a rectangular shape (DeCamp et al., 2016).

This biomechanical configuration is predisposed to fractures at multiple sites, a variety of combinations, displacement of its components, and narrowing of the pelvic canal. Obstipation and dystocia in females often result from untreated traumatic pelvic fractures in which there is narrowing of over $45 \%$ of the pelvic

Recebido em 23 de agosto de 2017

Aceito em 17 de maio de 2018

*Autor para correspondência (corresponding author)

E-mail: gustavogosuen@gmail.com canal (Meeson and Corr, 2011). In cats, stenosis of the pelvic canal due to trauma leads to obstipation with subsequent megacolon, which is characterized by hypomotility and irreversible distension of the intestinal segment (Bertoy, 2002).

Prompt correction of traumatic pelvic fractures improves patient prognosis (Meeson and Corr, 2011). Rectal palpation is required to verify pelvic canal narrowing and rectal perforation (DeCamp et al., 2016). Orthopaedic and neurological examination (Meeson and Corr, 2011), and direct image analysis (Kemper et al, 2011) are essential for a precise diagnosis and prognosis. Surgical repair is recommended when 
there are fractures of the cranial portion of the acetabulum, pelvic canal narrowing, neurological damage, ipsilateral fractures, contralateral orthopaedic lesion, or failure of conservative treatment (Labler, 2005; Kemper et al, 2011).

Some techniques are recommended to widen the narrowed pelvic canal, such as triple osteotomy of the pelvis (Ferguson, 1996), symphysectomy with the use of allogenic bone grafts as distractors (Prassinos et al, 2007), and external or internal hemipelvectomy. Hemipelvectomy is recommended in cases of neoplasia or after a great trauma. Internal hemipelvectomy consists in the removal of bone fragments from the pelvis with preservation of the ipsilateral limb, while external hemipelvectomy is characterized by the concomitant amputation of the ipsilateral limb (Lopes et al, 1994).

The aim of this report was to describe the technique of caudal partial internal hemipelvectomy as rescue treatment in four cases of obstipation due to traumatic pelvic canal narrowing in dogs.

\section{CASE DESCRIPTION}

Four dogs with similar history of stabilized or non-stabilized chronic fracture of the pelvis, dyschezia, and constipation were admitted to the Small Animal Surgical Clinic of the "Governador Laudo Natel" Veterinary Hospital, UNESP - Universidade Estadual Paulista, Campus Jaboticabal - SP, Brazil, from 2012 to 2016.

Case 1: A 3-year-old mixed breed bitch, weighing $9 \mathrm{~kg}$, was admitted with a history of progressive constipation and ribbon-shaped stools following a road traffic accident that took place 1 year ago (Figure 1A). Rectal palpation indicated pelvic canal stenosis, which was confirmed by simple radiography. After failure of conservative treatment based on laxatives, and recurrence of faecaloma, partial hemipelvectomy was indicated (Figure 1B).

Case 2: A 7-month-old poodle bitch, weighing $3.9 \mathrm{~kg}$, was admitted with history of recent road traffic accident and loss of hindlimb function. Palpation during initial physical examination revealed bilateral fracture of the pelvis, absence of medial and lateral reflex arcs, and lack of lateral deep nociception on the left hindlimb, suggestive of sciatic nerve damage. Radiographic evaluation revealed severe bilateral multiple fractures of the pelvis (Figure 1C). Two months after bilateral ilium osteosynthesis with screws and bone cement (Figure 1D) the animal began to show signs of progressive dyschezia and dysuria. Radiography revealed displacement of both ilia (Figure 1E), leading to stenosis of the pelvic canal and obstipation, and thus requiring bilateral partial hemipelvectomy (Figure 1F).

Case 3: A 3-year-old mixed breed male dog, weighing $7 \mathrm{~kg}$, was admitted with the diagnosis of pelvic fracture (Figure 1G) and history of road traffic accident 4 days prior, tenesmus, and progressive achezia and anuria. The ilia were stabilized with screws and bone cement (Figure 1H). Six months later, the animal was readmitted with history of progressive tenesmus. Radiography of the pelvis and abdomen revealed narrowing of the pelvic canal (Figure 1I) with presence of developing faecaloma unresponsive to conservative management or surgery (enterotomy). Left partial internal hemipelvectomy was recommended (Figure 1J).

Case 4: A 3-year-old mixed breed male dog, weighing $1.2 \mathrm{~kg}$, was admitted with history of progressive tenesmus after trauma by motor vehicle accident 1 year ago. Rectal palpation revealed narrowing of the pelvic canal, presence of faecaloma, and old fracture of both hemipelvis (Figure 1K). Two months after faecaloma surgery and colonpexia, there was recurrence of clinical signs. Thus, left partial hemipelvectomy was indicated (Figure 1L).

The animals were placed in dorsal decubitus following completion of the anaesthetic protocol and extensive trichotomy of both hindlimbs and hemipelvis. Prior to asepsis and draping, rectal palpation was performed to evaluate the stenosis of the pelvic canal immediately prior to surgery for post-operative evaluation. 


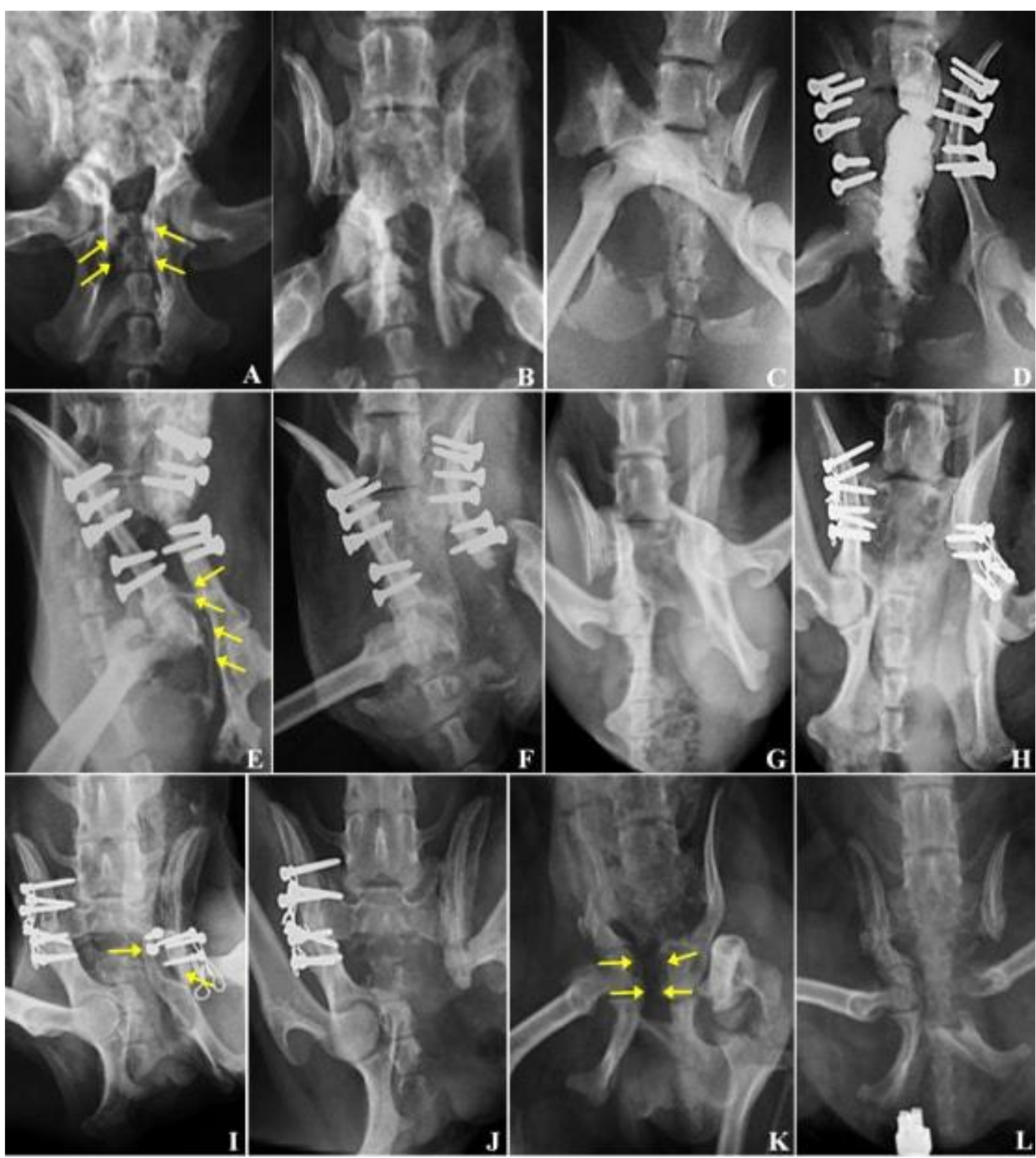

Figure 1: Radiographic images (ventrodorsal projections) of canine pelvis pre and post-surgery of internal partial caudal hemipelvectomy (four cases). A-B: (Case 1). A: image 1 year after road traffic accident and severe pelvic canal stenosis (arrows). B: post-operative image after removal of the pubis and part of the ischia. C-F: (Case 2). C: multiple fracture of the pelvis. D: bilateral osteosynthesis of the ilium with screws and bone cement. E: marked displacement of the right ilium causing severe stenosis of the pelvic canal (arrows). F: excision of the distal left ilium, including the acetabulum, left colocephalectomy, bilateral removal of the pubis and left ischium. G-J: (Case 3). G: multiple fracture of the pelvis. H: bilateral osteosynthesis with screws and bone cement. I: loss of stability of osteosynthesis of the left ilium (arrows) when compared to the post-operative image of the osteosynthesis. J: excision of the left distal ilium, including the acetabulum, left colocephalectomy, bilateral removal of the pubis and left ischium. K-L: (Case 4). K: image 1 year after road traffic accident and severe pelvic canal stenosis (arrows). L: excision of the left distal ilium, including the acetabulum, left colocephalectomy, bilateral removal of the pubis and cranial portion of the left ischium. 
Skin incision was made overlying the pubic symphysis and the musculature retracted for visualization of the obturator foramen. In Case 1, two osteotomies were performed using a pneumatic oscillating saw: one on the pubis, bilaterally, close to the acetabulum; and the other on the ischium, bilaterally, removing the bone set combined to adjacent soft tissues that showed intense fibrosis. It is important to note that in all cases not only the osteotomized bone fragments, but also any other fragments that were loose or attached to the muscle, were carefully dissected to minimize damage to neighbouring soft tissues. In Cases 2, 3, and 4, the osteotomy of the left hemipelvis was performed on the ilium, cranially to the acetabulum. The left femur head ligament was sectioned, and the bone fragments dissected and removed. Ostectomy of the acetabulum and arthroplastic excision of the femoral head and neck were performed through the same access point due to acetabulum displacement (Cases 3 and 4) and existing neurological damage (Case 4). The left excision in Case 2 was decided upon based on the rectal palpation findings before and during surgical intervention as well as in providing better locomotive support of the right hindlimb.

Muscle and subcutaneous tissue were sutured with synthetic monofilament absorbent suture $\left(\right.$ Caprofil $^{\circledR}$ ) using single interrupted and single continuous pattern, respectively. Skin suture was performed using single interrupted pattern and synthetic monofilament non-absorbable suture (nylon).

In all patients, celiotomy was performed to remove retained faecal content. Milking of intestinal loops through the pelvic canal was met with no resistance in all four cases. The suture planes of the celiotomy were performed as previously described. At the end of the surgical procedure, rectal palpation detected no resistance in the pelvic canal, as previously noted by the passing of the faecal content during manual milking of the intestine (Table 1).

Table 1. Data from patients submitted to hemipelvectomy procedure, including breed, weight, age, sex, width of the canal at the cranial portion of the sacrum (Sacrum), pre and post-operative width between the medial cortices of both acetabulum (Ac-Ac) and pre and post-operative sacral index (S. I.)

\begin{tabular}{|c|c|c|c|c|c|c|c|c|c|}
\hline \multirow{2}{*}{ Pacient } & \multirow{2}{*}{ Breed } & \multirow{2}{*}{ Weight } & \multirow{2}{*}{ Age } & \multirow{2}{*}{ Sex } & \multirow{2}{*}{ Sacrum } & \multicolumn{2}{|c|}{$\mathrm{AC}-\mathrm{AC}$} & \multicolumn{2}{|c|}{ S. I. } \\
\hline & & & & & & Pre & Post & Pre & Post \\
\hline 1 & MB & $9 \mathrm{~kg}$ & $3 y$ & $\mathrm{~F}$ & $2,6 \mathrm{~cm}$ & $1 \mathrm{~cm}$ & $1,3 \mathrm{~cm}$ & 0,38 & 0,65 \\
\hline 2 & Poodle & $3,9 \mathrm{~kg}$ & $7 \mathrm{~m}$ & $\mathrm{~F}$ & $1,8 \mathrm{~cm}$ & $1 \mathrm{~cm}$ & $1,8 \mathrm{~cm}$ & 0,55 & 1 \\
\hline 3 & MB & $7 \mathrm{~kg}$ & $3 y$ & M & $2,5 \mathrm{~cm}$ & $0,8 \mathrm{~cm}$ & $1,6 \mathrm{~cm}$ & 0,3 & 0,64 \\
\hline 4 & MB & $1,2 \mathrm{~kg}$ & $3 y$ & M & $1,5 \mathrm{~cm}$ & $0,3 \mathrm{~cm}$ & $1,1 \mathrm{~cm}$ & 0,2 & 0,77 \\
\hline
\end{tabular}

MB - Mixed Breed

Sacrum - Width of the canal at the cranial portion of the sacrum

Ac-Ac - Width between the medial cortices of both acetabula

S. I. - Sacral index: Calculated as the ratio between the width of the canal at the cranial portion of the sacrum and the width between the medial cortices of both acetabulum.

Post-operative therapy consisted of tramal $^{\circledR}$ (Tramadol hydrochloride; Pfizer, Brazil), lisador $^{\circledR} \quad$ (Dipyrone plus promethazine hydrochloride plus adiphenine hydrochloride, Farmasa, Brazil), cefalexina ${ }^{\circledR}$ (Cephalexin, Medley, Brazil), label $^{\circledR} \quad$ (Ranitidine hydrochloride, Medley, Brazil), and lactulona ${ }^{\circledR}$ (Lactulose, Daiichi Sankyo, Japan) and the surgical wound was cleaned with saline solution and Rifocina spray ${ }^{\circledR}$ (Rifamycin spray, Sanofi, Brazil) every 8 hours until suture removal.

All animals showed normochezia immediately after surgery, which continued even after lactulone was suspended at 10 days postoperative. Weight bearing on the ipsilateral hindlimb was observed on the first week after partial internal hemipelvectomy in 3 out of the 4 cases reported, and full function recovered between the $10^{\text {th }}$ and $20^{\text {th }}$ day post-surgery, with the exception of Case 2, in which the left hindlimb remained non-functional due to neurological damage. Case 3 required physiotherapy but showed excellent progress. Animals were followed up for approximately 60 days and, once there was no recurrence of tenesmus or dyschezia, the animals were discharged. 


\section{DISCUSSION}

The present report highlights the greater occurrence of multiple fractures in the pelvis, corroborating other retrospective studies (Kemper et al, 2011). Pelvic fractures (especially of the ilium) with medial dislocation of the fragments, when not adequately treated, result in pelvic canal stenosis (Meeson and Corr, 2011) with progressive constipation and accumulation of faeces in colon and rectum (Bertoy, 2002), as observed in all cases presented in this report.

In $11 \%$ of cases of pelvic lesions, medial dislocation of the fractured fragments leads to sciatic nerve damage, as observed in Case 2 (Lee et al, 2012). However, contrary to the observed in the majority of cases, there was no spontaneous recovery (DeCamp et al, 2016), possibly due to the intensity of the trauma.

The diagnosis of pelvic canal stenosis was obtained by history of trauma, clinical signs of tenesmus and dyschezia, rectal palpation, and simple and contrast-enhanced image analysis (DeCamp et al, 2016, Bertoy, 2002, Kemper et al, 2011).

Despite update recommendations for planning and diagnosis based on advanced imaging such as electromagnetic resonance and specially computed tomography that allows a threedimensional evaluation, we decided for radiographic evaluation in respect for the patient's owner's personal reasons and also for the possibility of performing the diagnosis of pelvic fractures and pelvic canal stenosis (Crawford et al, 2003; Draffan et al., 2009).

Pelvic canal measurements can be used to make pre-operative decisions and post-operative evaluations aimed at widening the narrowed pelvic canal. The sacral index is calculated as the ratio between the width of the canal at the cranial portion of the sacrum and the width between the medial cortices of both acetabulum (Hamilton et $a l, 2009)$. In cats, sacral index of $0.97+/-0.025$ is considered normal and surgical correction is recommended when this index is reduced by 0.33 or more (Hamilton et al, 2009). Similar data could not be found in dogs, and therefore could not be applied to the cases reported.
There are few comparative post-operative studies on patients subjected to different techniques of widen the pelvic canal; however, Schrader (Schrader, 1992) reported 62\% recurrence in pelvic canal stenosis due to loosening of implants following pelvic osteotomies stabilized with plates and screws. Ferguson (1996) reported a case of successful pelvic osteotomy fixated with plate and screws but with no removal of bone fragments. Few reports are available on symphysectomy or symphysiotomy with the use of spacers to correct pelvic canal stenosis; furthermore, its execution has the limitation of requiring integrity of the pubic symphysis (Prassinos et al, 2007).

To be deemed successful, hemipelvectomy surgery must meet two requirements: functional recovery of the pelvic limb(s) and resolution of obstipation (DeGroot et al, 2016). All cases presented in this report met the above requirements, demonstrating the success of this therapy. The one exception to functional recovery was the animal in Case 2, as previously discussed.

\section{CONCLUSION}

The results obtained in the cases reported support the efficacy of uni or bilateral caudal partial internal hemipelvectomy technique as rescue therapy for obstipation secondary to traumatic pelvic canal narrowing, in four dogs.

\section{REFERENCES}

BERTOY, R.W. Megacolon in the cat. Vet. Clin. N. Am. Small Anim. Pract., v.32, p.901-915, 2002.

CRAWFORD, J.T.; MANLEY, P.A.; ADAMS, W.M. Comparison of computed tomography, tangential view radiography, and conventional radiography in evaluation of canine pelvic trauma. Vet. Radiol. Ultrasound, v.44, p.619628, 2003.

DeCAMP, C.E; JOHNSTON, S.A.; DÉJARDIN, L.M.; SCHAEFER, S.L. Fractures of the pelvis. In: DeCAMP, C.E; JOHNSTON, S.A.; DÉJARDIN, L.M.; SCHAEFER, S.L (Eds.). Handbook of small animal orthopedics and fracture repair. 5.ed. St. Louis, Missouri: Saunders Elsevier, 2016. p.437-467. 
DeGROOT, W.; GIBSON, T.W.G.; REYNOLDS, D., MURPHY, K.A. Internal hemipelvectomy for treatment of obstipation secondary to pelvic malunion in 3 cats. Can. Vet. J., v.57, p.955-960, 2016.

DRAFFAN, D.; CLEMENTS, D.; FARRELL, M. et al. The role of computed tomography in the classification and management of pelvic fractures. Vet. Comp. Orthop. Traumatol., v.22, p.190-197, 2009.

FERGUSON, J.F. Triple pelvic osteotomy for the treatment of pelvic canal stenosis in a cat. $J$. Small Anim. Pract., v.37, p.495-498, 1996.

HAMILTON, M.H.; EVANS, D.A.; LANGLEYHOBBS, S.J. Feline ilial fractures: assessment of screw loosening and pelvic canal narrowing after lateral plating. Vet. Surg., v.38, p.326-333, 2009.

KEMPER, B.; GONÇALVES, L.P.; VIEIRA, M.O. et al. Consequências do trauma pélvico em cães. Ciênc. Anim. Bras., v.12, p.311-321, 2011.

LABLER, L.; TRENTZ, O.; KEEL, M. Traumatic hemipelvectomy. Eur. J. Trauma, v.6, p.543-550, 2005.
LEE, K.; HENG, H.G.; JEONG, J.; NAUGHTON, J.F. et al. Feasibility of computed tomography in awake dogs with traumatic pelvic fracture. Vet. Radiol. Ultrasound, v.53, p.412416, 2012.

LOPES, A.; PENNA, B.; ROSSI, B.M.; WU, T.C.; TANAKA, M.K. Hemipelvectomia total interna no tratamento dos tumores malignos da regiäo pélvica. Rev. Bras. Ortop., v.29, p.787790, 1994.

MEESON, R.; CORR, S. Management of pelvic trauma: neurological damage, urinary tract disruption and pelvic fractures. J. Feline Med. Surg., v.13, p.347-361, 2011.

PRASSINOS, N.N.; ADAMAMA-MORAITOU, K.K.; GOULETSOU, P.G.; RALLIS, T.S. Symphyseal distraction-osteotomy using a novel spacer of spirally fashioned orthopaedic wire for the management of obstipation. J. Feline Med. Surg., v.9, p.23-28, 2007.

SCHRADER, S. Pelvic osteotomy as a treatment for obstipation in cats with acquired stenosis of the pelvic canal: Six cases (1978-1989). J. Am. Vet. Med. Assoc., v.200, p.208-213, 1992. 